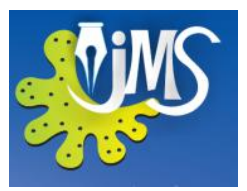

\title{
Traditional Agricultural Practices Unique to Meemure Village, Kandy District Sri Lanka
}

\author{
Tharaka Ananda $^{1}$ and Charmalie Nahallage ${ }^{1}$ \\ 1Department of Sociology and Anthropology,
}

University of Sri Jayewardenepura

\begin{abstract}
Meemure, located in the Central Province, in Kandy District, $343 \mathrm{~km}$ from Colombo is one of the unique villages in Sri Lanka that has about five hundred years of history and is remaining isolated from the main society with its own specific culture. Village prehistory has built on mythical stories related to "King Rawana" as well as folklores centered around a Vedda name "Beduruwa"; owner of the village during King Wimaladharmasuriya I (1542-1604). Due to its isolation from the main society many of the early traditions are still been preserved in this community. Therefore the main objective of this research is to study the traditional agricultural practices that are unique to them which they inherited from their forefathers. This is a descriptive study which used qualitative data collection methods. Questionnaire survey was conducted using seventy informants representing one person from each family and in depth interviews were conducted with five individuals. The study was conducted from April to November, 2013. Ninety percent of the Meemure villagers were farmers. Results revealed that the majority of the agricultural practices in Meemure village are unique to them. In paddy cultivation "Aluyanthraya adima", traditional paddy storing system- "Vee atuwa" and many religious practices as well as land apportion system-"Pendi weta" (fence) and the methods used to construct the "Chena pala" in Chena cultivation cannot be seen in other cultures. However there is a gradual decrease in the usage of these practices nowadays thus it is necessary to record and protect these diminishing cultures.
\end{abstract}

KEYWORDS Diminishing cultures, Folk lore, Religious practices, Chena cultivation 


\section{INTRODUCTION}

Meemure village is located in Central province, in Kandy district [N 07.433330 and E 08.833330] (http://en.wikipedia.org/wiki/Meem ure). It belongs to Ududumbara Secretariat Division and to Meemure Grama Niladari Division. Total population according to census in 2011 in Meemure GN division consists of 331 people belonging to 115 families (Primary Data Collection Report 2011: Ududumbara).

The main objective of this research was to study traditional agricultural practices unique to Meemure villagers that they have inherited from their forefathers. Meemure village is famous for its prehistorical myths surrounding King Rawana. According to the Meemure legend, the Lakegala Mountain is considered as Kingdom Lankapura which was King Ravana's capital. King Rawana had one of his abodes on its peak, and that his kingdom of Lankapura surrounded by "Yaksha" (Ranasinghe, 1995, p5). Even today they believe about the "Yaksha" guardians of King Rawana that protect their village (Lokubandara, 1959, p8). There are many folklore related with that story and it is said that Meemure and another villages around the Lakegala Mountain to be inheritance of King Ravana's "Yakka tribe".

Thus Meemure village has known to be habituated by people in the era of King Wimaladharmasuriya I (1542-1604). Vedda named "Beduruwa" had followed bees to collect honey from "Maraka" (village in Kandy District) to Meemure area. He had seen the area which can live without much trouble with full of natural resources. Thus he had requested the Meemure village from king and had settled in the Meemure for hunting and collecting honey on behalf of the palace too. Later two men from "Poddalgoda" (village in
Kandy District) named "Herath Hami" and "Riti Hami" had been there for hunting. They had seen the rich natural conditions in Meemure area, thus they had planned and killed "Beduruwa Vedda" to own the land. Thereafter they had settled there with their families.

The first inhabitants of the Meemure village had been depending on chena and paddy cultivations for food. The traditional knowledge system they had used has been passed down through generation to generation. This knowledge system shows significant characteristics that cannot be seen in other areas of the country.

\section{MATERIALS AND METHODS}

This is a descriptive study which used qualitative data collection methods. Seventy families were selected randomly from the village to gather information for the questionnaire. In depth interviews were done with five individuals who were knowledgeable about Meemure village and its Traditional Agricultural Practices. Study was conducted from April to November 2013.

\section{RESULTS AND DISCUSSION}

\subsection{Traditional paddy cultivation method in Meemure village.}

Traced paddy cultivation method can be seen in Meemure village. All the work in paddy field starts with an auspicious time. First stage of the paddy cultivation is removing the weeds (aswanatha suddakirima) and cleaning the canals (ela payanawa). Then ploughing the paddy field starts (bim nagum heeya) with the begining of "ak wahi" (small rain) in "duruthu maha" (January). Meemure villagers have buffalos for plough, if not enough few can be 
collected from the neighbourhood. Then farmers break the earth in to smaller bits with the mamoty (Bimnagum ketima) and level the mud with a flat board (govilalla) (porugama or adduma).

In preparing the paddy field for sowing, one farmer selects an auspicious day and time to start work and inform fellow farmers about the time; except Sundays, and Tuesdays they use Mondays, Thursdays and Fridays for sowing. They start sowing together in all the fields on the same time after lighting a lamp to Buddha and they chant nine virtues of the Buddha while sowing for the first time. They use one variety of paddies for entire kumburu yaya (stretch of paddy land) in the village. Traditionally they have cultivated many paddy varieties such as sudu vee, heenati vee, kalu vee, kalu kumara vee, murugakayan and pachcha perumal.

On the third day after sowing, water was supplied to the field for the first time ("palamu issanmuraya"). Palamu issanmuraya is very important; water must be spread in to the entire field otherwise the places that water have not filled give opportunity for weeds to grow. Thus farmer goes around and checks the field to see if the water was supplied to the entire field. Careful water management system protects the field from the weeds. One thing they do for the protection of the filed from weeds is careful water management. As the fields begin to mature farmer increase the level of the water course (wakkada) and control the water level of the field. When harvesting is reached paddy covers the earth and prevent sunlight from falling on the earth. During this stage weeds cannot grow as sunlight is absent.
As a tradition the chief householder to whom the paddy field belongs goes to the neighbour houses with sheaf of betel leaves and invites them for the harvesting. Neighbours get betel as the amount of the members that they can supply for the harvesting. In this way the farmer can decide the amount of the men would be participating for harvesting by counting the rest of the betel in the sheaf of betel leaves. He prepares all the requirements for the harvesting day such as sickles, food, betel, sweets according to the number that will participate. This is called "aththama". This "aththama" goes as a circle until the harvesting of entire "kumburuyaya" (stretch of paddy land). This enables self-help amongst the villagers.

The preparation of the 'kamata' (the place where the cut paddy is threshing and storing) is done by the owner of the kumburuyaya. He cleans the floor at an auspicious time in the morning then applies cow dung on it. Kamatha is open round place that make in the middle of the kumburuyaya. On the ground of the kamatha farmer draw "Aluyanthraya" as an elaborate ritual. It is drawn using sifted ash that's why it called "Aluyanthraya". Ash gets on to the jack tree leaf and pour on to the ground of the kamatha to get a traditional design of aluyanthraya. They started to draw aluyanthraya chanting "namothassa bagawatho..." stanza.

This aluyanthraya consists of seven circles. First circles is made of Hirassa vine (Cissus quadrangularis), few of paddy, karal haba - (Achyranthes aspera) leafs and boo leafs (Ficus religiosa). These leafs enwrap together by madu vel (Merremia tridentate) and enfold it using thola boo (Crinum asiaticum) leafs as a coil (daranduwa). This called "tholabo 
walalla" and placed it on the first circle in the aluyanthraya. Then coconut, wormwood (Azadirachta indica), conch and colter (hee vela) placed on the tholabo walalla (on the first circle of the aluyantharaya). Then plough (nagula), mamoty (udalla), sickle (dakaththa) and yoke (wiyagaha) are placed around the "aluyanthraya".

First cut paddy bundle was put on the coconut which is placed in the middle of the "aluyanthraya", by the owner of the paddy field and worship all directions to get the blessing from Lord Buddha and deities. This coconut is use to make milk rice to offer the lord Buddha after harvesting.
After this "aluyanthraya" custom the cut paddy was brought to 'kamata' in bundles. These bundles were collected into a circular heap, which is called Goyam Kolaya. Buffaloes are used to thresh the paddy. The process is called 'kola madeema'. The first portion of the harvest is kept aside for the alms of Lord Buddha and the deities. All the duties in the kamatha are done by with much respect.

\section{2 "Vee Atuwa"- Traditional Paddy Storing System}

Meemure villagers use "vee atuwa" to store their paddy. This is particular to the Meemure village. "Vee atuwa" or paddy storage was built above the ground on four rocks called "Atu

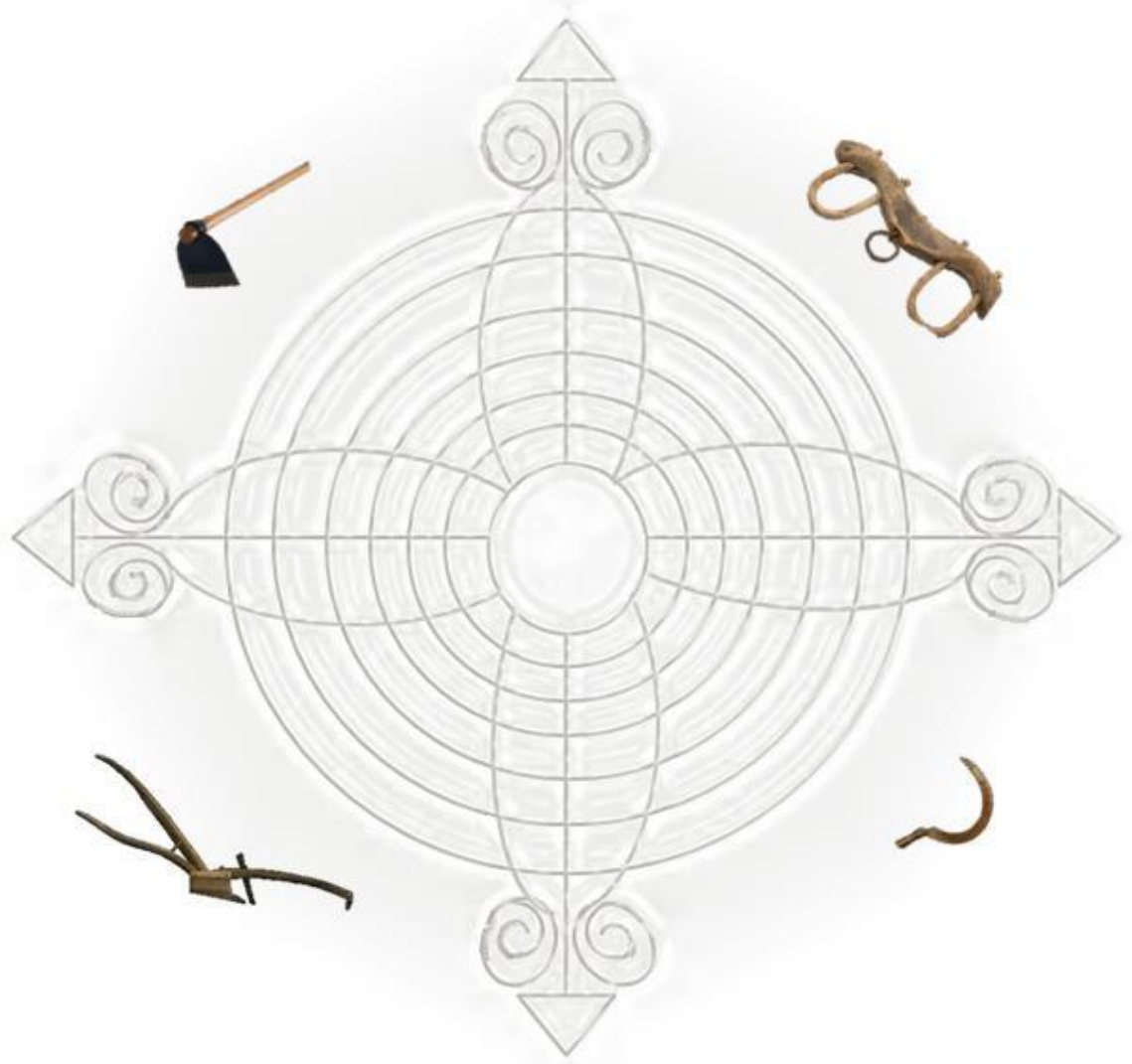

Figure 1 "Aluyantharaya" 
karu" inside the house. Thus it gives protection to the grains from rodents, insects and also from the climate changes. Atuwa is made of jack tree wood (Artocarpus heterophyllus) which is considered as a lucky tree. First a wooden layer placed on the rocks. Walls were made on the wooden layer by using slats tied with "kiri vel" (Ichnocarpus frutescens). Spaces between slats are filled by clay balls. Then wattle and daub are applied on to the walls. Outside of the walls were polished by lime and inside walls by cow dung. Then it was covered by flap made of wood.
This vee atuwa is the only vee atuwa in Meemure village that has been built in accordance to the methods of traditional knowledge. Thus it has nominated to preserve as it is one of the archeologically significant monuments in Meemure village. However no action was taken up to now to conserve this and the owner of this house, Mr. Punchi Banda is going to build new house in this land after breaking this old house with vee atuwa. Three years before he had agreed to preserve this atuwa as archeologically significant monument but Archaeology Department of Kandy has not given their attention yet.

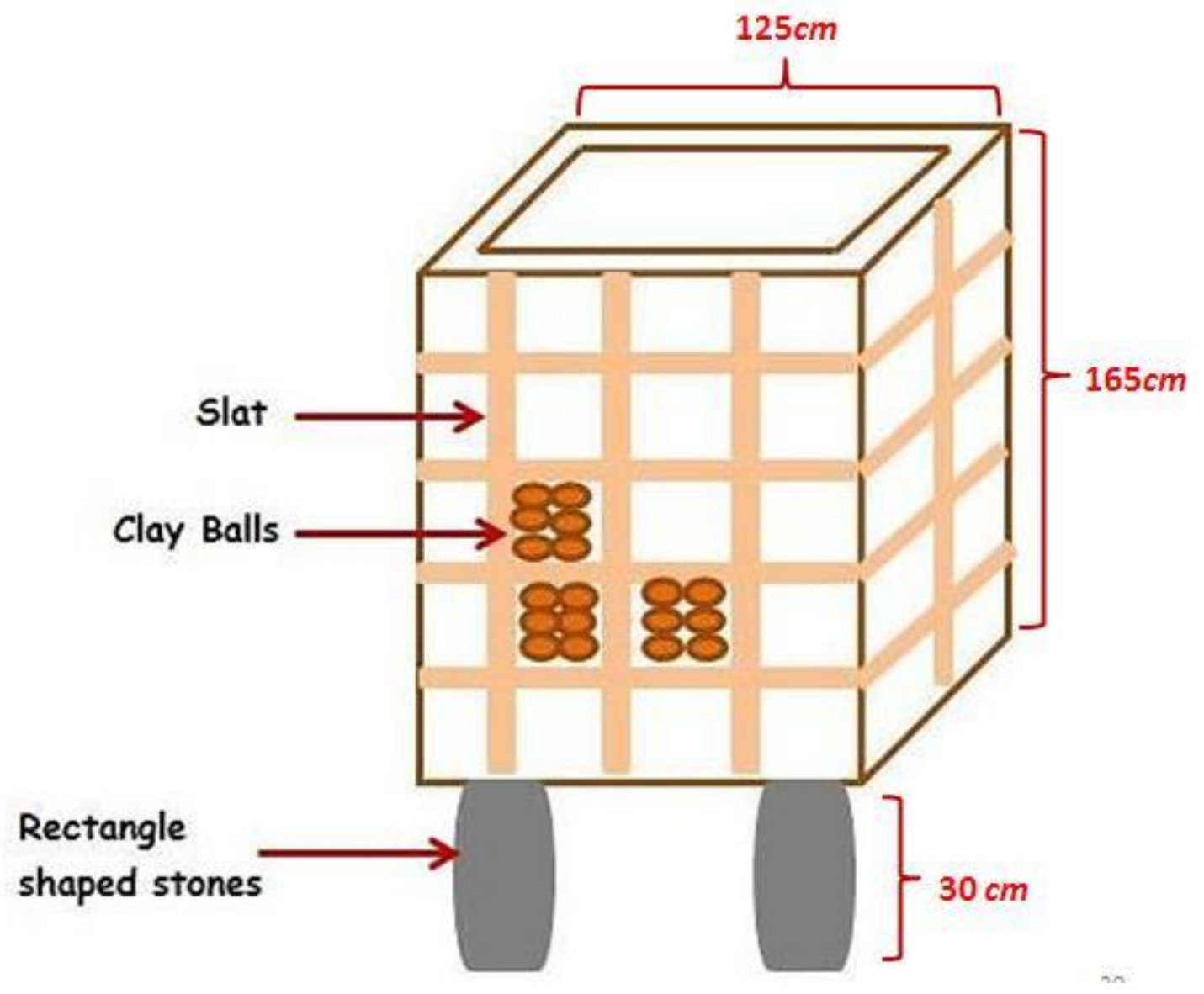

Figure 2 Structure of the "Vee Atuwa" 

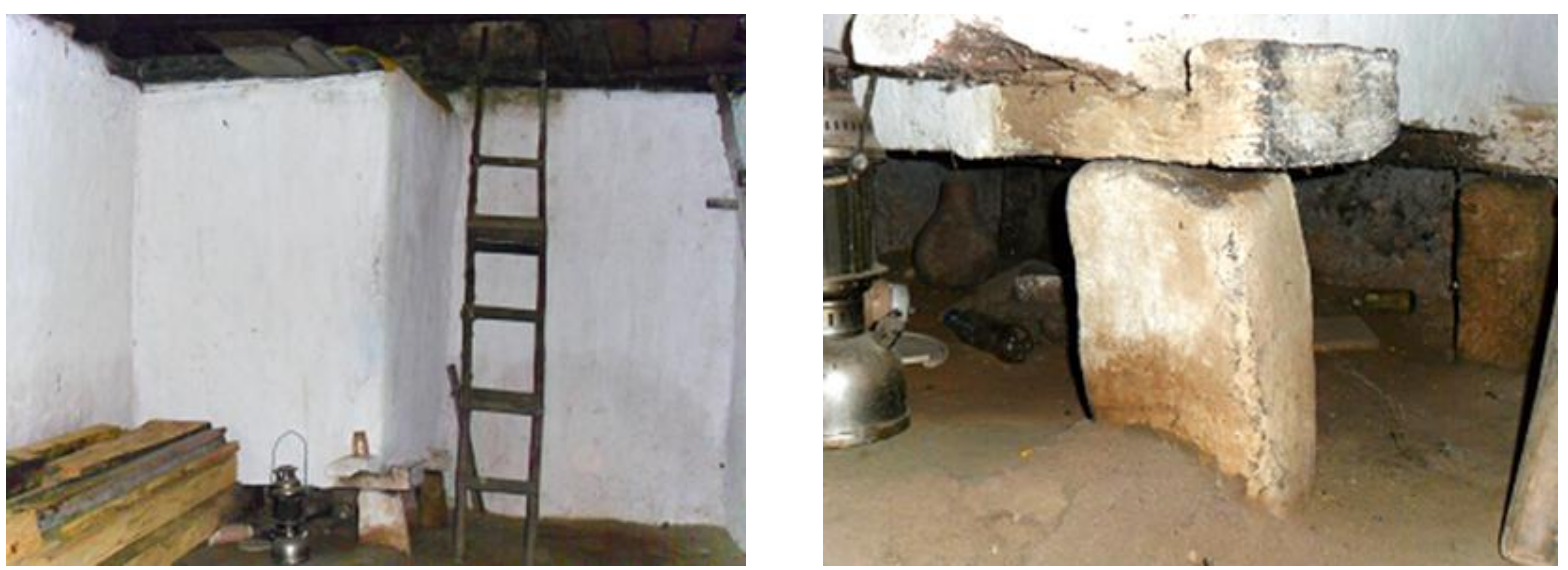

Figure 3 "Vee Atuwa"

3.3 Traditional Chena Cultivation practices in Meemure Village

Chena cultivation was the major subsistence agricultural method of Meemure villagers about 20 years ago. In 1988 Chena cultivation was prohibited by the government due to the requirement of the preservation of knuckles Mountain range. Thus from 1988 Meemure villagers have abandon their Chena cultivations and had been used to depend only on the paddy cultivation. Their systems of Chena cultivation are different from other Chena cultivations that can be found in other villages.

They do not have legal conveyance for the land. There are no legal owners for those lands and they had been cultivating in these lands by the inheritance from their older generations. If someone does not have a land they can request a land from the owners for one season.

In August villagers fixed an auspicious date and time for the slash of the land. Well grown forest called as "Kathi Kalaya" must be slashed by catty (kaththa). The forests that must be used knife for the slash called "Pihiya kale".
Slashing period continue for 7 or 8 days. Then all the branches in large trees were cut, it is called "athu kandu bama". Then slashed forests are allowed to dry for 15 days or a month.

In September, when "binara rain" ("binara kolla") reached they begin to work again on the land. They start to burn the slashed and dried forest from the bottom of the land; to make it easy for the fire to spread. Before burning the forest all the farmers shout loudly saying "kura gana bada gana saththu duwapiyoo" (all the animal run, escape from the fire). After three or five days from burning of the forest farmers start to clean the land.

Next real work of the Chena begin; the building of the "pala" (shack) and "pendiwata" (stockade around the Chena) with charred logs. Major task in the chena cultivation is making strong fence. Productivity of the Chena cultivation system depends on the extent of the protection that can be supply at any cost. Thus the fundamental task of the chena cultivation is to build a strong and protective fence around the chena which would not let small size animals such as rodents, 
rabbits, porcupine and wild pigs, deer etc., enter to the chena.

Traditional fence in Meemure, which goes around the Chena, is called "pendi wata" and it is particular to the Meemure village. "Pendi wata" is made of timbers that collected from the burnt forest. Before start building the "pendi wata" farmers fixed an auspicious time. They start to begin the fence mostly at night. All the farmers start to make their fences in their Chena at the same time. For the beginning place of the "pendi wata" they use "divi kaduru" timber and "madu vel". (As they believe this "divi kaduru" timber and "madu vel" are lucky to use in the beginning of the fence). After beginning of the fence on auspicious time in the night, rest of the pendi wata was made in the morning on the next day. The system of making "pendi wata" is significant and effective.

First in the bottom of the land forked prop placed and timbers places in order to fill the forked prop. The spaces between timbers were filled with stones or small logs. To start the "pendi wata" they select cliff place or any other place that prevent animals entering to the chena such as boulder or peak place of the chena land. Timbers that filled on the forked prop makes an appearance as cocks comb (penda) and that is the reason this fence called as "pendi wata".

Next task is the building of the "pala" (shack). First prop of the pala (pal karuwa) was placed on auspicious time. Then cow dung was applied on to the floor of the pala and walls were made of timbers which is called "Dandu biththiya". Roof is thatched. Inside the pala there are many parts that were used for different purposes. This small pala consists of places for storing grains, place to cook, place to sleep and place to arrange goods.

In front of the pala there is a small rectangular shaped flat ground to spread and dry the "kurakkan" (Eleusine coracana) called "Madilla". Farmers stay in pala till the harvest ends and move back to their permanent houses after the season finished.

At an auspicious time first seeds, such as long beans (Vigna unguiculata), buck wheat (Fagopyrum esculentum), kurakkan, undu (Phaseolus mungo), thala (sesame), pumpkin (Cucurbita maxima), and cucumber (Cucumis sativus) are thrown in to one small ground in the Chena which about $5 \mathrm{~m}^{2}$. They do not consume the crops of this ground as a tradition. Then land was divided in to sections and sow verity of seeds in each sections such as tobacco (Nicotiana tabacum), long bean, chilies, and manioc, ladies fingers, cucumber, pumpkins, brinjols (Solanum melongena), bitter gourd, batu karwilla, dambala, tumba, green gram (mun-Phaseolus aureus), meneri (Paspalum scrobiculatum) and aba (Brassica juncea). Pits are made in between each seven feet on the ground. About five or six buck wheat seeds and about three long bean seeds are put in to it. 


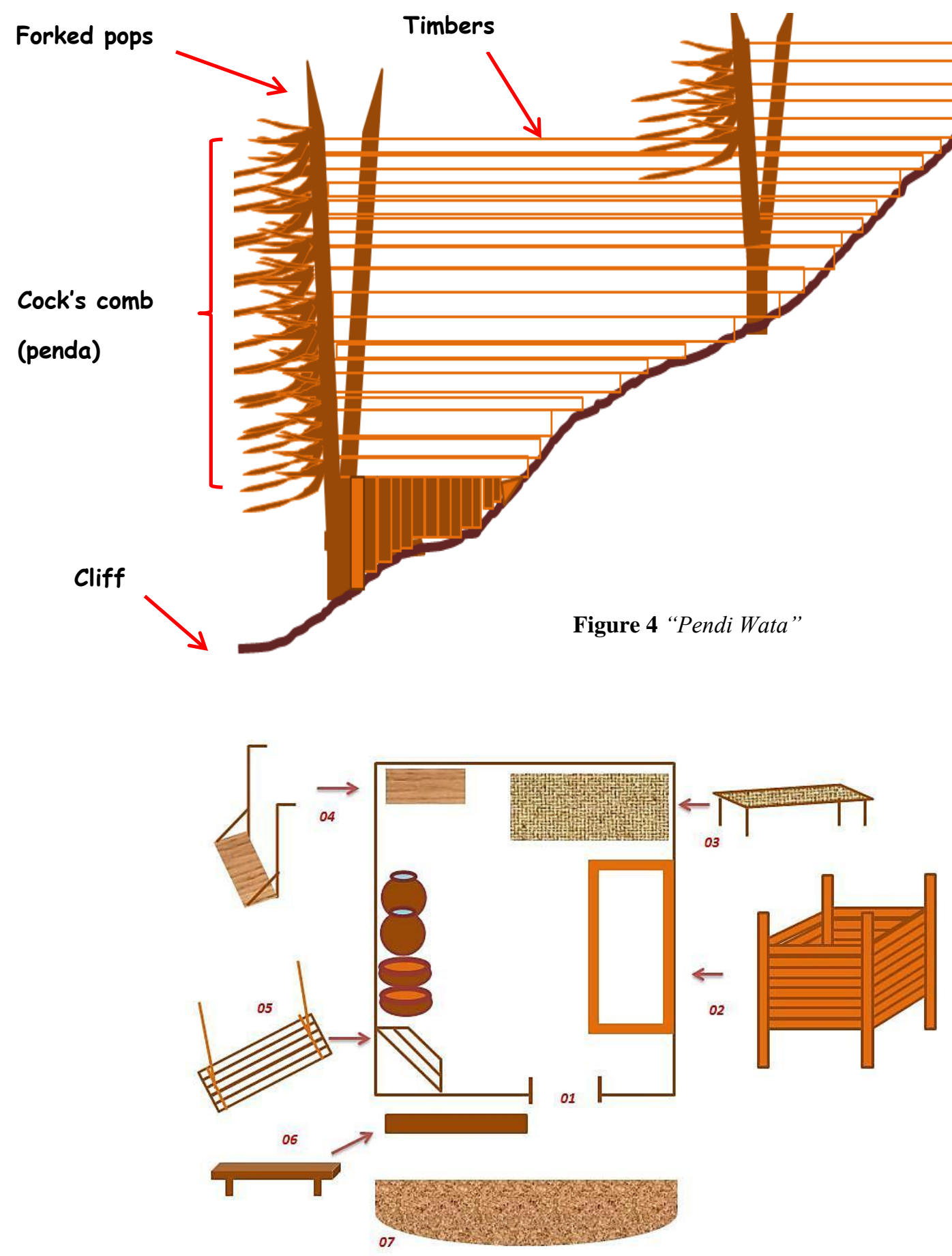

01 Entrance

02 "Kurakkan Massa" (wooden "kurakkan" store)

03 "Nidi massa" ( Bed)

04 "Wel massa" ( Rack for cloths and rice)
05 "Dum massa"

06 "Oththappuwa" ( Bench)

07 “Madilla"(Ground place for dry "kurakkan”) 
Buck wheat plants will be the sticks for the long beans and farmer do not want to place sticks anew. When two or three sprouts appears in buck wheat plants farmers start to sow kurakkan. In "Nawam maha" (January) comes the "kurakkan" harvesting period. Then all the villagers get busy with the harvesting. All the vegetables and crops are taken in to the house. They separate first portion of the harvest in to a labu kataya for the lord Buddha and for the deities. (This separated harvest is offered to the deities on the day of the "adukku pujawa or "adukku” ritual).

Then the Chena is abandoned at least for eight years and allowed to revert to their natural vegetation. After the cycle end they come to the land where they first began to cultivate. This was their major cyclical method of food source 20 years ago. And their staple food was kurakkan which now have been replaced by rice as a result of the prohibition of Chena cultivation.

\section{"Iringu aduththa" and "Iringu uga" -} "Iringu aduththa" and "iringu uga" is one of buck wheat storing system. Peels of the corns tie together to make-iringu aduththa and those iringu aduthu hang on the cord in the corner of the kitchen and it called iringu uga. And labu ketaya also use in Chena cultivation for store grains and also as water pot.

"Pathan" (Grass lands) -"Pathan" or grasslands are mountain lands that had been used for chena cultivations 20 years ago. These Pathan can be seen around Meemure village such as "Palle pathana", "Uda pathana", "Kirimatiya", "Gaduma". At present they use this Pathan as a fertile ground for their cattle and buffalos to live freely. They do not nourish their cattle or buffalos in their gardens or any other places inside the village. Pathan is rich in grasses and water for the cattle. When the paddy cultivation starts they bring their cattle and buffalos back to the village. And after the paddy cultivation they bring them back to the pathan let them freely until next paddy cultivation season. Around the pathana they have built a fence it prevent cattle from entering into the nearest forests.

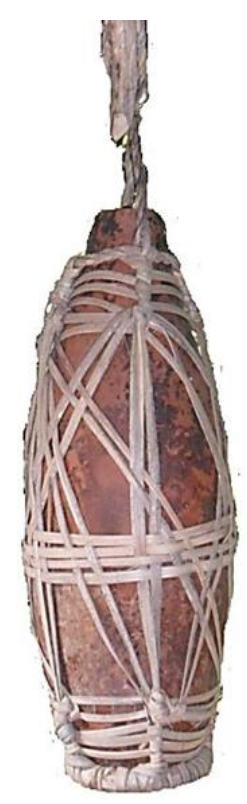

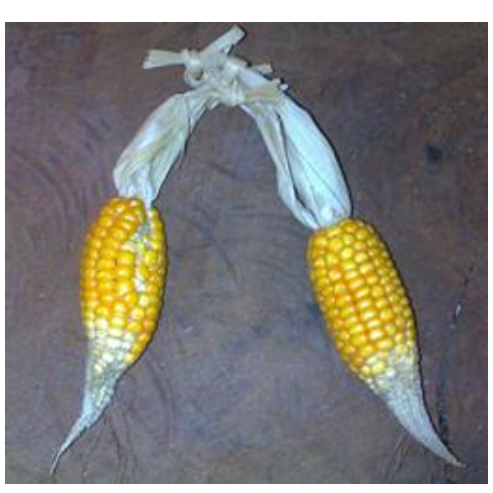

B

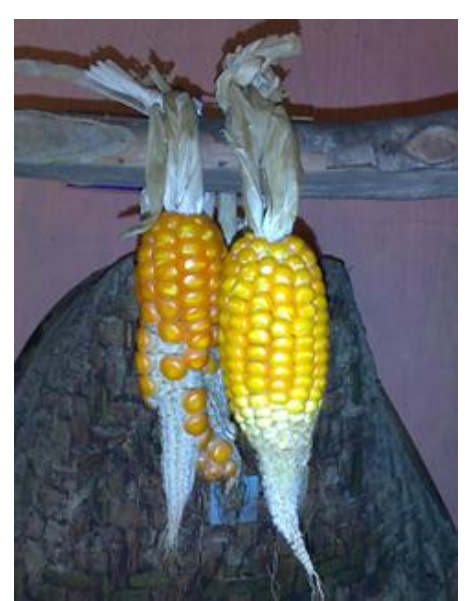

C

Figure 6 A: Labu Ketaya B: Iringu Aduththa C: Iringu Uga 

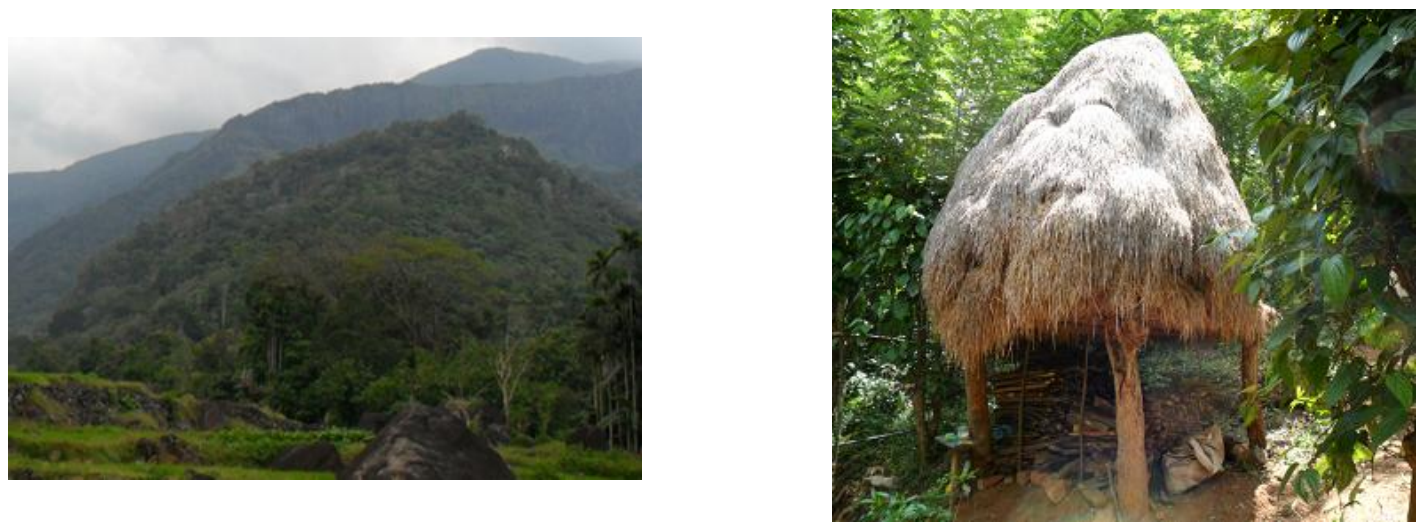

Figure 7 Grass lands (Left) "Piduru Panthala" (Right)

"Piduru panthala"- This is a mushroom shaped hey store. This hey is to feed the cattle after they bring to the village in paddy cultivation season (for ploughing and threshing). Piduru panthala is made above the ground on 4 timbers to arrange hey.

\section{DisCUSSION}

From the beginning, the people of Meemure have been depending on Chena cultivation and Paddy cultivation. In 1988 Chena cultivation was legally prohibited from Meemure village for the conservation of the knuckle's Mountain region(http://www.forestdept.gov.lk/web/index. php)

option=com_content $\&$ view $=$ article $\&$ id $=114 \&$ It emid=116\&lang=en). Thus the traditional knowledge of the Chena cultivation now is limited only to the older generation of the Meemure village and Prohibition of Chena cultivation has disentitled culturally specific traits and their main foods source.

Before the prohibition of the Chena cultivation; both cultivations had supplied all of their food needs without any inconvenience. Today $90 \%$ of villagers are famers and had bounded only to the paddy cultivation method and face lots of hardships to fulfill their food supply. One has to go $38 \mathrm{~km}$ to Hunnasgiriya town to get vegetables or other needs. From the Meemure village one had to travel through a difficult road by the only van that they have for transportation. Therefore they have grown some vegetables in their gardens but it is not sufficient for all the food needs.

In spite of losing their daily food needs they are losing their valuable cultural heritage too. In Meemure village only the older generation holds the last link to the storehouse of indigenous knowledge system of these traditional cultivation practices. Younger generation do not want this knowledge moreover as they do not subsist on agriculture. Exodus of the younger generation to the cities majority as labors have made the village desolated. They do not seem to give attention to the valued cultural practices as those do not fulfill their requirements today as 20 years before. At present the Meemure villagers tend to cultivate only paddy and traditional paddy verities cannot be seen, but some practices that have passed through 500 of years.

This diminishing culture must be protected. But we cannot capture culture; a 
dynamic, hugely variable phenomenon and preserve it in a museum or lab. Preserving the communities as a living reservoir of culture is the best methods that can apply for the protection of the cultures like this. In addition, modern communication technologies can be used to record the countless practices and memories the indigenous knowledge and oral history of these communities (http://nalakagunawardene.com/tag/moji-riba/).

At last all the responsible governing bodies must give their attention for the villagers like Meemure. Government has named Knuckles Mountain as world heritage but who had taken the responsibility of vanishing their cultural heritage and their innocent life style? Without understanding human nature and human cultural adaptations there will not be a future. Our forefathers depended on the natural resources and there were no concept of conservation acts of forests, mountains, rivers, but they have lived together with the nature without contaminating or destroying it. They respect nature as their mothers. Legal acts for conservation nature had started after industrial revolution. Until then traditional knowledge system of our ancestors had protected the nature.

Meemure villagers too had used natural techniques for their Chena cultivation. Without better understanding of their culture Sri Lankan government had taken actions that were partly responsible for the disappearance of some of the cultural traditions of these people. Therefore the most timely action for the preservation of the Meemure culture is to educate the Meemure people about the importance of preserving their unique culture. They should understand the importance of their culture then only others could take action to help them to preserve it. This should happen not only to the Meemure people but to all the other diminishing cultures in Sri Lanka.

\section{REFERENCES}

FOREST DEPARTMENT - SRI LANKA. (2013). World Heritage Sites. [Online] Sri Lanka: Forest Department. Available From: http://www.forestdept.gov.lk/web/index.php ?option=com_content $\&$ view $=$ article $\&$ id $=114$ \&Itemid=116\&lang=en $\quad$ (Accessed: $02^{\text {nd }}$ April 2014).

LOKUBANDARA, W. M. (1959). Lakegala, Sri Lanka, 11(02), January, p. 8.

MEEMURE. (2014). [Online] Available from: http://en.wikipedia.org/wiki/Meemure (Accessed: $10^{\text {th }}$ October 2013).

GUNAWARDENA, N. (2009 Jan 26). Moji Riba and Mountain Eye: A Digital Home Capsule. [Online].Available from: http://nalakagunawardene.com/tag/moji-riba/ (Accessed: 10 ${ }^{\text {th }}$ October 2013).

RANASINGHE, P. B. (1955). Laggala Ithihasaya, Sri Lanka, 07 (7), June, p. 5. 